\title{
Complicated retropharyngeal abscess: an atypical cause of myelopathy
}

\author{
Abscesso retrofaríngeo complicado: uma causa atípica de mielopatia \\ Natália Vasconcellos de Oliveira SOUZA', Erica Navarro ADISSY', Ana Beatriz Ribeiro FONSECA², \\ Barbara GREGGIO², Barbara TRAPP², Carolina Candeias DA SILVA' , Maria Elisabeth FERRAZ1
}

Retropharyngeal abscess is a possible etiology for spinal cord syndrome, with often delayed diagnosis ${ }^{1}$. A 46-year-old immunocompetent male presented with a progressive 2-month history of severe neck pain, intermittent fever, weight loss and dysphagia, and weakness and numbness in the lower and upper limbs. In addition, he had urinary incontinence and fecal retention.
A cervical spine MRI scan was performed and showed a complicated retropharyngeal abscess, with significant compression of the spinal cord (Figure 1). The abscess was drained by the surgical team; however, there was no complete neurological recovery. The present report reinforces the importance of an early surgical approach in order to achieve a better functional prognosis ${ }^{2}$.

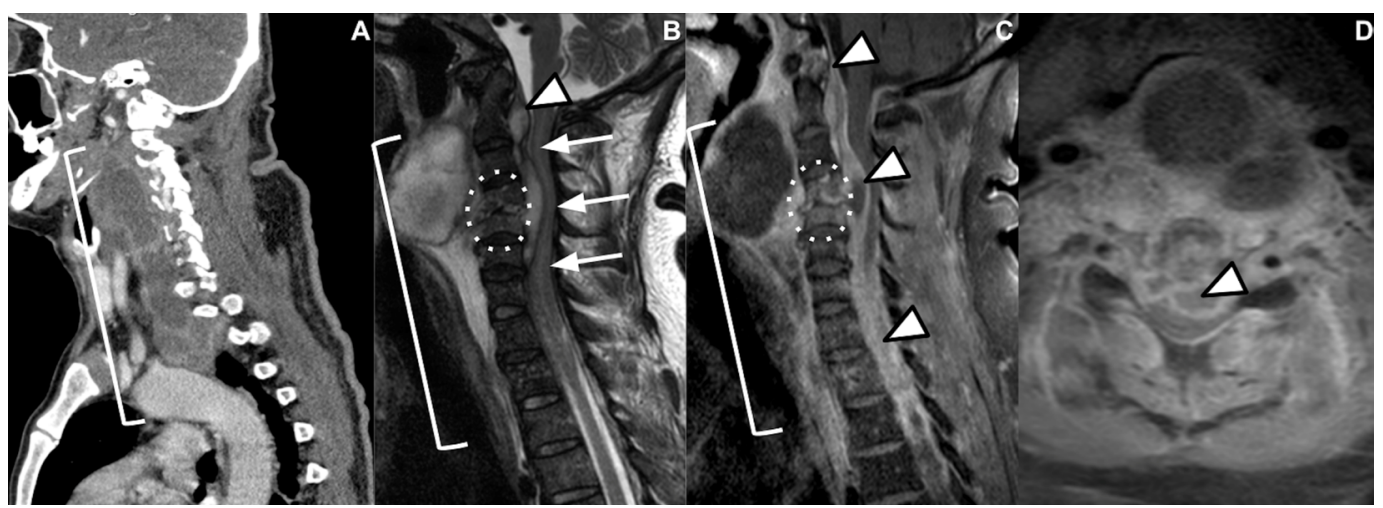

Figure 1. Post-contrast para-sagittal neck CT (A) and cervical spine MRI sagittal T2 (B); sagittal T1 (C), and axial T1 (D) weighted post-contrast images. Large collection involving the prevertebral/retropharyngeal space for review only (brackets), extending from the oropharynx to the upper mediastinum level, in close relation to the aortic arch and promoting marked reduction of the oropharynx and hypopharynx air columns. A posterior extension of the infectious/inflammatory process is observed, with involvement of the C4 and C5 vertebral bodies (osteomyelitis), the C4-C5 intervertebral disc (discitis) (both assigned with a dotted circle) and a large anterior epidural empyema (arrowheads), extending from the craniocervical junction to the cervicothoracic transition, promoting a marked narrowing of the vertebral canal and compression of the cervical spinal cord, with signs of myelopathy/myeloedema (arrows), especially at the level of C4-C5.

\section{References}

1. Bandopadhyay SN, Mukherjee D, Mukherjee D, Banerjee S, Sen SK. Adult retropharyngeal abscess. Indian J Otolaryngol Head Neck Surg. 2015 Apr;23(1):7-11. https://doi.org/10.47210/bjohns.2015.v23i1.30
2. Dudas R, Serwint JR. In Brief: Retropharyngeal Abscess. Pediatr Rev. 2006 Jun;27(6):e45-6.https://doi.org/10.1542/pir.27-6-e45

\footnotetext{
${ }^{1}$ Universidade Federal de São Paulo, Departamento de Neurologia e Neurocirurgia, São Paulo SP, Brazil.

${ }^{2}$ Universidade Federal de São Paulo, Departamento de Cirurgia de Cabeça e Pescoço, São Paulo SP, Brazil.

${ }^{3}$ Universidade Federal de São Paulo, Departamento de Radiologia, São Paulo SP, Brazil.

Natália Vasconcellos de Oliveira SOUZA (ID https://orcid.org/0000-0002-1032-5787; Erica Navarro ADISSY (D) https://orcid.org/0000-0002-4296-6941; Ana Beatriz Ribeiro FONSECA (iD https://orcid.org/0000-0002-7716-0884; Barbara GREGGIO iD https://orcid.org/0000-0002-5420-0513; Barbara TRAPP (iD https://orcid.org/0000-0001-5554-6674; Carolina Candeias DA SILVA (D) https://orcid.org/0000-0003-2661-779X; Maria Elisabeth FERRAZ (iD https://orcid.org/0000-0002-8192-9211
}

Correspondence: Natália Vasconcellos de Oliveira Souza; E-mail: nat.vasconcellosouza@gmail.com

Conflict of interest: There is no conflict of interest to declare.

Authors' contribution: Souza NVO: conception, organization, execution, manuscript and writing of the first draft. Adissy EN: organization, execution, manuscript and writing of the first draft. Fonseca ABR: organization, execution, manuscript, review and critique. Greggio B: organization, execution, manuscript, review and critique. Trapp B: conception and organization. Candeais C: writing of the first draft, review and critique. Ferraz ME: conception, organization, execution, manuscript, writing of the first draft, review and critique.

Received on May 27, 2020; Received in its final form on June 16, 2020; Accepted on June 23, 2020. 